\title{
Non-specific Bacterial Profiles in Reproductive Tract of Dairy Cattle during Artificial Insemination
}

\author{
Astin Islam Andriani ${ }^{1}$, Sri Pantja Madyawati ${ }^{1 *}$, and Emy Koestanti Sabdoningrum ${ }^{2}$ \\ ${ }^{I}$ Department of Veterinary Reproduction, Faculty of Veterinary Medicine, Universitas Airlangga, Surabaya-60115, Indonesia \\ ${ }^{2}$ Department of Veterinary Animal Husbandry, Faculty of Veterinary Medicine, Universitas Airlangga, Surabaya-60115, Indonesia \\ *Corresponding author's Email: sripantja_madyawati@yahoo.com; (DORCiD: https://orcid.org/0000-0002-0624-1580
}

\begin{abstract}
One of the causes of low reproductive efficiency in dairy cattle is the presence of reproductive disorders caused by a non-specific bacterial infection. The aim of the present study was to isolate and identify the genus of non-specific bacteria in the reproductive tract of dairy cattle during artificial insemination. A total of 10 samples in the form of mucus attached to the plastic sheath used after artificial insemination in dairy cattle were collected in the study. The samples were subjected to bacterial isolation and identification. The obtained results of the study indicated that Staphylococcus was the dominant genus found (90\%). On the other hand, other genera were Escherichia (60\%) and Corynebacterium (20\%).
\end{abstract}

Keywords: Artificial Insemination, Dairy Cattle, Non-Specific Bacteria, Reproductive Tract

\section{INTRODUCTION}

Dairy cattle have good prospects to be developed by farmers and breeders in Indonesia. However, breeders have the most fundamental problem that is the low production efficiency due to reproductive failure in dairy cattle. This will cause a decrease in the population of dairy cattle (Hastono and Adiati, 2020). In addition, dairy cattle have a low conception rate (Gani et al., 1970). Generally, reproductive tract infections by non-specific bacteria are considered to be the main causes of repeated conception failures (Gupta and Sharma, 2006; Nesa et al., 2011).

The handling of reproductive diseases caused by bacterial, viral, fungal, and parasitic pathogens affects the reproductive health status of the cattle. If it is not handled properly, it will cause reproductive disorders and can cause temporary infertility until permanent sterility (Hariadi et al., 2011). Bacterial infection of cattle is divided into two types; bacterial infections caused by specific and non-specific bacteria. Non-specific bacteria is normal bacteria that exist in nature and can enter the reproductive tract of dairy cattle, the bacteria will become pathogenic if there are injuries that can cause inflammation. The postpartum uterine is a good environment for bacterial growth because it has a warm, fluidfilled condition and contains a number of necrotizing debris (Blanc et al., 2002).

One of the dairy cattle reproductive techniques is Artificial Insemination. Artificial insemination of cattle, especially cows, is being programmed by the government in an effort to increase cattle income and welfare. In intensive agriculture areas, Infectious bronchitis (IB) is often used because of limited bull cattle (Hadi, 2002). The use of artificial insemination technology can be used to control sexually transmitted diseases and it is one of the ways to improve reproductive efficiency (Hafez and Hafez, 2013). Bacterial infection is found in artificially inseminated cows by 52\% whereas it is reported as $21.21 \%$ in naturally mated cows and in the developed countries reproductive disorders caused by bacteria can reach $2-13 \%$ (Nesa et al., 2011). In Indonesia, from $20.44 \%$ of reproductive disorders cases of dairy cattle, $2-5 \%$ are suspected of a bacterial infection.

Village Unit Cooperative is one of the institutions in the countryside as a place to facilitate the success and achievement of programs made by the government. KUD Wilis is one of the Village Unit Cooperative that has a large number of dairy cattle. This place was chosen because almost $90 \%$ of the people in the area are involved in the dairy farming business with average ownership of 3-8 dairy cattle. The purpose of this study was to determine the profile of non-specific bacteria that is present in the dairy cattle reproductive tract during artificial insemination. 


\section{MATERIALS AND METHODS}

This study was conducted in the Wilis Village Unit Cooperative area, Sendang District, Tulungagung Regency, Indonesia, and microbiological examination was carried out in the Bacteriology and Microbiology Laboratory, Department of Microbiology, Faculty of Veterinary Medicine, Universitas Airlangga, Surabaya.

The research equipment used for this study was a plastic sheath, plastic gloves, IB gun. Sampling equipment was sterile scissors, cool box with a temperature of $4^{\circ} \mathrm{C}$, plastic, and tissue. Microscopic observation included glass objects, glass covers, and microscopes. Equipment for the manufacturing of isolation media was Petri dishes, pipettes, bunsen fires, Erlenmeyer tubes, digital scales, and measuring cups.

The material of the study was mucus attached to the plastic sheath which was used after artificial insemination of dairy cattle. The media used for the temporary sample was PBS solution, while the media for isolation was Tripticase Soya Agar (TSA), Blood Agar (BA), Manitol Salt Agar (MSA), and Methylene Blue Agar (EMBA). The ingredients for Gram staining are Violet Crystals, safranin solution, alcohol acetone, and Lugol. The catalase test used 3\% $\mathrm{H} 2 \mathrm{O} 2$ solution and the spore test used malachite green and safranin solution. For further test used the media of TSIA, SIM, MR-VP, and confectionery solution.

The design of the study was an observational method with a laboratory explorative research design by isolating and identifying genus of non-specific bacteria in the reproductive tract of dairy cattle during artificial insemination. Samples in the form of mucus attached to the plastic sheath during artificial insemination were isolated using general and selective media. Samples were then observed macroscopically, microscopically, and continued with biochemical tests.

The sampling technique used in this study was based on the number of villages in the Tani Wilis Village Unit Cooperative area of 11 villages. Samples were randomly taken from 11 villages in cattle when insemination was carried out, then the 10 mucus samples that attached to the plastic sheath were isolated and identified.

Analysis of the data in this study was in the form of a non-specific bacterial genus found in the reproductive tract of dairy cattle when artificial insemination was tabulated and displayed descriptively.

\section{RESULTS}

Research on the non-specific bacteria isolation of 10 mucus samples attached to the plastic sheath of the dairy cattle reproductive tract during artificial insemination in KUD Tani Wilis, Sendang District, Tulungagung Regency indicated the results of Gram-positive and Gram-negative bacteria.

Observation result of the colony in 4 seed media, namely TSA, BA, EMBA, and MSA, incubated at $37^{\circ} \mathrm{C}$ for 24 hours indicated 6 green metallic colonies on EMBA media, 9 yellow/ red colonies on MSA media, and 2 white colonies on TSA/BA media. The Gram staining showed that there were six samples in the form of red Cocobacilos Gramnegative (Figure 1), nine samples in the form of purple Coccus or Gram-positive (Figure 2), and two isolates in the form of purple Bacillus or Gram-positive (Figure 3).

The analysis results of the Catalase test, Spore test, Motility test, TSIA, maltose in each sample that has been carried out isolation can be found non-specific bacteria. The catalase test was used on 9 isolate samples which were Gram-positive Coccus bacteria namely in sample numbers of 1, 3, 4, 5, 6, 7, 8, 9, and 10. The nine samples had a positive catalase test in accordance with Table 1 by the formation of oxygen bubbles after dripping with a solution of hydrogen peroxide (H2O2) 3\%. For the genus of bacteria found in the nine samples, namely Staphylococcus.

The results of the isolated samples in the form of Gram-positive Bacilli were in sample numbers 8 and 9. In these samples, the spore test was carried out and the result was negative or non-spore. Motility test was also carried out on the two samples with non-motile results or the absence of bacterial growth in the puncture area. The result of the TSIA test showed $\mathrm{Al} / \mathrm{A}$ without gas and $\mathrm{H} 2 \mathrm{~S}$, VP test with negative result that was marked by the absence of discoloration in the media (still yellow) besides that the result of the maltose test was positive. The genus of bacteria found in both samples was the genus Corynebacterium.

The result of the isolated sample in the form of Coccobacilli Gram-negative, namely in the samples 1, 2,3,7,8, and 9, had metallic green colonies on EMBA media. motility test with motile and TSIA result with A/ A result, gas positive, negative H2S, from these results can be concluded that the Escherichia genus bacteria was obtained. The content of nonspecific bacteria in the reproductive tract of dairy cattle during artificial insemination was the genus Staphylococcus 90\%, genus Escherichia 60\%, and genus Corynebacterium $20 \%$. 


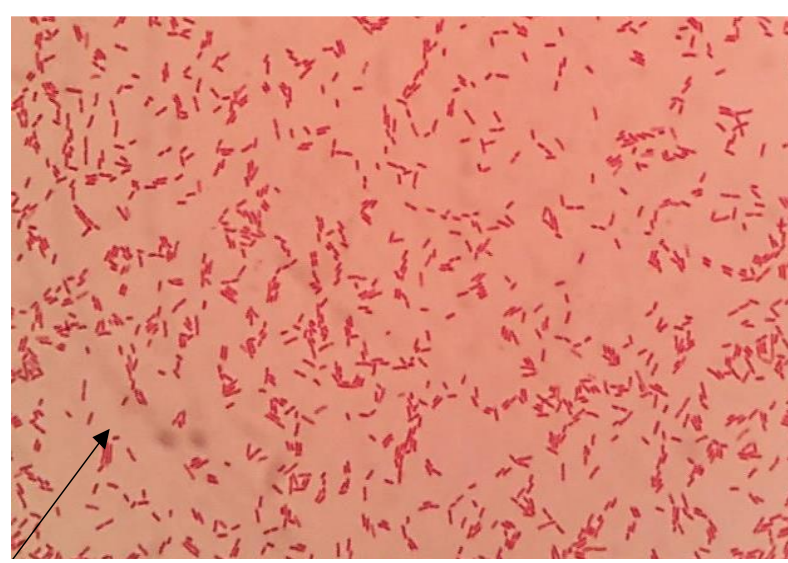

Figure 1. Six samples in the form of red Cocobacilos Gram-negative on microscopic examination with 1000 $\mathrm{x}$ magnification.

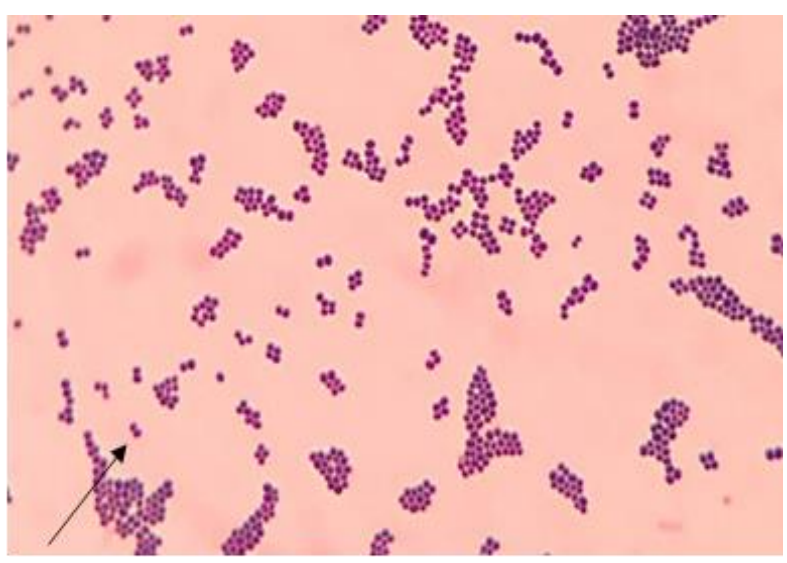

Figure 2. Nine samples in the form of purple Coccus or Gram-positive on microscopic examination with $1000 \mathrm{x}$ magnification.

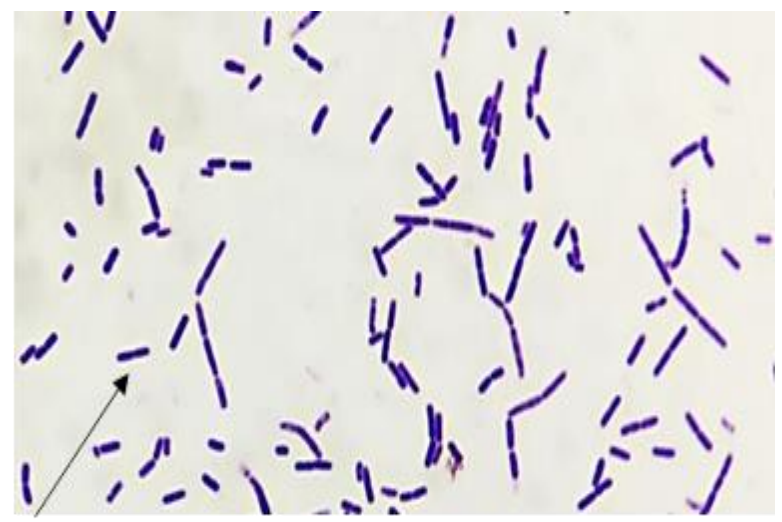

Figure 3. Two isolates in the form of purple Bacillus or Gram-positive on microscopic examination (1000 $\mathrm{x}$ magnification).

Table 1. Analysis result of non-specific bacteria in the mucus of the reproductive tract of dairy cattle during artificial insemination.

\begin{tabular}{|c|c|c|c|c|c|c|}
\hline Sample & Gram Staining Result & \multicolumn{4}{|c|}{ Identification Result } & Genus \\
\hline \multirow{2}{*}{1} & Coccus, Gram-positive & \multicolumn{4}{|c|}{ Catalase Test: Positive } & Staphylococcus \\
\hline & Coccobacilli, Gram-negative & Motility Test: Motile & \multicolumn{3}{|c|}{ TSIA: ${ }^{\mathrm{A}} / \mathrm{A}$, gas positive, $\mathrm{H}_{2} \mathrm{~S}$ negative } & Escherichia \\
\hline 2 & Coccobacilli, Gram-negative & Motility Test: Motile & \multicolumn{3}{|c|}{ TSIA: ${ }^{\mathrm{A}} / \mathrm{A}$, gas positive, $\mathrm{H}_{2} \mathrm{~S}$ negative } & Escherichia \\
\hline \multirow{2}{*}{3} & Coccus, Gram-positive & \multicolumn{4}{|c|}{ Catalase Test: Positive } & Staphylococcus \\
\hline & Coccobacilli, Gram-negative & Motility Test: Motile & \multicolumn{3}{|c|}{ TSIA: ${ }^{A} / A$, gas positive, $\mathrm{H}_{2} \mathrm{~S}$ negative } & Escherichia \\
\hline 4 & Coccus, Gram-positive & \multicolumn{4}{|c|}{ Catalase Test: Positive } & Staphylococcus \\
\hline 5 & Coccus, Gram-positive & \multicolumn{4}{|c|}{ Catalase Test: Positive } & Staphylococcus \\
\hline 6 & Coccus, Gram-positive & \multicolumn{4}{|c|}{ Catalase Test: Positive } & Staphylococcus \\
\hline \multirow{2}{*}{7} & Coccus, Gram-positive & \multicolumn{4}{|c|}{ Catalase Test: Positive } & Staphylococcus \\
\hline & Coccobacilli, Gram-negative & Motility Test: Motile & \multicolumn{3}{|c|}{ TSIA: ${ }^{A} / A$, gas positive, $\mathrm{H}_{2} \mathrm{~S}$ negative } & Escherichia \\
\hline \multirow{3}{*}{8} & Coccus, Gram-positive & \multicolumn{4}{|c|}{ Catalase Test: Positive } & Staphylococcus \\
\hline & Bacil, Gram-positive & Spore Test: Non-spore & $\begin{array}{l}\text { TSIA: }{ }^{\mathrm{A}} / \mathrm{A}, \text { gas } \\
\text { positive, } \mathrm{H}_{2} \mathrm{~S} \\
\text { negative }\end{array}$ & $\begin{array}{c}\text { VP: } \\
\text { Negative }\end{array}$ & $\begin{array}{l}\text { Maltose: } \\
\text { Positive }\end{array}$ & Corynebacterium \\
\hline & Coccobacilli, Gram-negative & Motility Test: Motile & TSIA: ${ }^{\mathrm{A}} / \mathrm{A}, \mathrm{ga}$ & ositive, $\mathrm{H}_{2}$ & egative & Escherichia \\
\hline \multirow{3}{*}{9} & Coccus, Gram-positive & \multicolumn{4}{|c|}{ Catalase Test: Positive } & Staphylococcus \\
\hline & Bacil, Gram-positive & Spore Test: Non-spore & $\begin{array}{c}\text { TSIA: }{ }^{A} / A, \text { gas } \\
\text { positive, } \mathrm{H}_{2} \mathrm{~S} \\
\text { negative }\end{array}$ & $\begin{array}{c}\text { VP: } \\
\text { Negative }\end{array}$ & $\begin{array}{l}\text { Maltose: } \\
\text { Positive }\end{array}$ & Corynebacterium \\
\hline & Coccobacilli, Gram-negative & Motility Test: Motile & \multicolumn{3}{|c|}{ TSIA: ${ }^{\mathrm{A}} / \mathrm{A}$, gas positive, $\mathrm{H}_{2} \mathrm{~S}$ negative } & Escherichia \\
\hline 10 & Coccus, Gram-positive & \multicolumn{4}{|c|}{ Catalase Test: Positive } & Staphylococcus \\
\hline
\end{tabular}


Based on the result of the study, it was found several non-specific bacterial genera, namely the Staphylococcus, Escherichia, and Corynebacterium. The Escherichia, Staphylococcus, and Corynebacterium can be isolated from the reproductive tract (Hariadi et al., 2011). These non-specific bacterial infections can cause reproductive disorders, such as pyometra, endometritis, infertility, repeated mating, prolonged anesthesia, and cases of abortion. The most common nonspecific bacterial genus was the Staphylococcus genus. The genus Staphylococcus which is a genus of gram-positive bacteria could enter through the help of cases of abnormal birth, such as, dystocia, and can be through the hand of nonsterile inseminator (Hariadi et al., 2011). The number of genus Staphylococcus can also be proved by the result of animal health officer statement in the area of KUD Tani Wilis which in this area many breeders assisting with the abnormal birth cases without the help of officer and the possibility of breeders were not paying attention to cleanliness, another case that often occurred was endometritis. The occurrence caused by parturition disorders, such as distokia, that was not handled properly can cause a purulent necrotic period that was very good for bacterial proliferation which subsequently develops into endometritis. One of the germs that often infect was environmental germs such as the genus Staphylococcus. These bacteria can enter from the outside due to the help of reproductive disorders or Artificial Insemination which was less lege artist (Gani et al., 1970). Besides, the genus Staphylococcus can be isolated from normal cow uterus in weak condition or the presence of injuries to the uterine mucosa (Messier et al., 1984).

There was the genus Escherichia allegedly due to the presence of feces around the reproductive tract that contains the bacteria remembered that the location of the anus adjacent to the genital tract. Causative factors associated with the infection of the genus Escherichia were the contaminated water sources, floor cleanliness, cow cleanliness, and dirt place (Sumatra, 2002). Cattle preservation in Indonesia was generally still very simple and traditional, cattle waste was left unmanaged, so the risk of the genus Escherichia infection in cattle was quite high (Hani et al., 2003). The genus Corynebacterium was a bacterium that often causes metritis and developed into pyometra. This genus usually lives on the mucosal surface of healthy animals. In low numbers, this bacterial group can cause repeated mating cases. (Hariadi et al., 2011). The genus Corynebacterium was widespread, especially in cattle breeding areas, and has also been found in cow's vagina. The causative organism usually reaches the vagina during mating, giving birth, after giving birth, or through blood circulation (Baya et al., 1992).

\section{CONCLUSION}

Non-specific bacteria found in the reproductive tract of dairy cattle during artificial insemination are the genus Staphylococcus, genus Escherichia and genus Corynebacterium. The genus that is commonly found in the reproductive tract is the genus Staphylococcus. None of the authors had an economical goal from this experiment

\section{Authors' contributions}

Madyawati was consulting advisor. The authors have highly Andriani and Sabdoningrum appreciated the cooperation for taking care of Dairy Cattle during the experiment period and helping in the process of experimental work. All authors approved the final draft of the manuscript for submission to this journal. Ethical issues (including plagiarism, consent to publish, misconduct, data fabrication and/or falsification, double publication and/or submission, and redundancy) have been checked by the authors.

\section{Competing interests}

Authors has no conflict of interest.

\section{REFERENCES}

Baya AM, Lupiani B, Bandín I, Hetrick FM, Figueras HA, Carnahan A, May EM, and Toranzo AE (1992). Phenotypic and pathobiological properties of Corynebacterium aquaticum isolated from diseased striped bass. Diseases of Aquatic Organisms. 14: 115-26. Available at: http://hdl.handle.net/10261/26052

Blanc SJL, Duffield TF, Leslie KE, Bateman KG, Keefe GP, Walton JS, and Johnson WH (2002). Defining and Diagnosis Postpartum Clinical Endometritis and Its Impact on Reproductive Performance in dairy Cows. Journal of Dairy Science, 85(9): 2223-22236. DOI: https://www.doi.org/10.3168/jds.S0022-0302(02)74302-6

Gani MO, Amin MM, Alam MGS, Kayesh MEH, Karim MR, Samad MA, and Islam MR (2008). Bacterial flora associated with repeat breeding and uterine infections in dairy cows. Bangladesh Journal of Veterinary medicine, 6(1): 79-86. Available at: https://www.banglajol.info/index.php/BJVM/article/view/1342

Gupta RS, and Sharma R (2006). A Review on medicinal plants exhibiting antifertility activity in males. Natural Product Radiance, 5(5): 389-410. Available at: http://nopr.niscair.res.in/bitstream/123456789/8007/1/NPR\%205(5)\%20389-410.pdf 
Hafez ES, and Hafez B (2013). Reproduction in Farm Animals. 7th edition. Lippincott Williams \& Wilkins, editor. Maryland: Dunfermline, p. 509. Available at: https://www.wiley.com/en-us/Reproduction+in+Farm+Animals\%2C+7th+Edition-p$\underline{9781118710289}$

Hariadi M, Hardjopranyoto S, Wurlina HA, Hermadi BU, Rimayanti IN, and Triana HR (2011). Buku ajar ilmu kemajiran pada ternak. Surabaya, Indonesia: Penerbit Airlangga University Press, pp. 94-112. Available at: https://opac.perpusnas.go.id/DetailOpac.aspx?id=544750

Hastono, and Adiati U (2020). Peningkatan efisiensi reproduksi sapi perah melalui kawin tepat waktu. semiloka nasional prospek industri sapi perah menuju perdagangan bebas. bogor, Indonesia: Balai Penelitian Ternak, pp. 135-139. Available at: https://docplayer.info/38527696-Peningkatan-efisiensi-reproduksi-sapi-perah-melalui-kawin-tepat-waktu.html

Messier S, Higgins R, Couture Y, and Morin M (1984). Comparison of swabbing and biopsy for studying the flora of the bovine uterus. The Canadian Veterinary Journal, 25(7): 283-288. Available at: http://www.pubmedcentral.nih.gov/articlerender.fcgi?artid=1790600\&tool=pmcentrez\&rendertype=abstract

Nesa A, Joy SD, and Faruk MO (2001). Isolation and identification of uterine microorganisms in postpartum dairy cows. Bangladesh Journal of Microbiology, 28(1): 19-23. DOI: https://www.doi.org/10.3329/bjm.v28i1.11804 